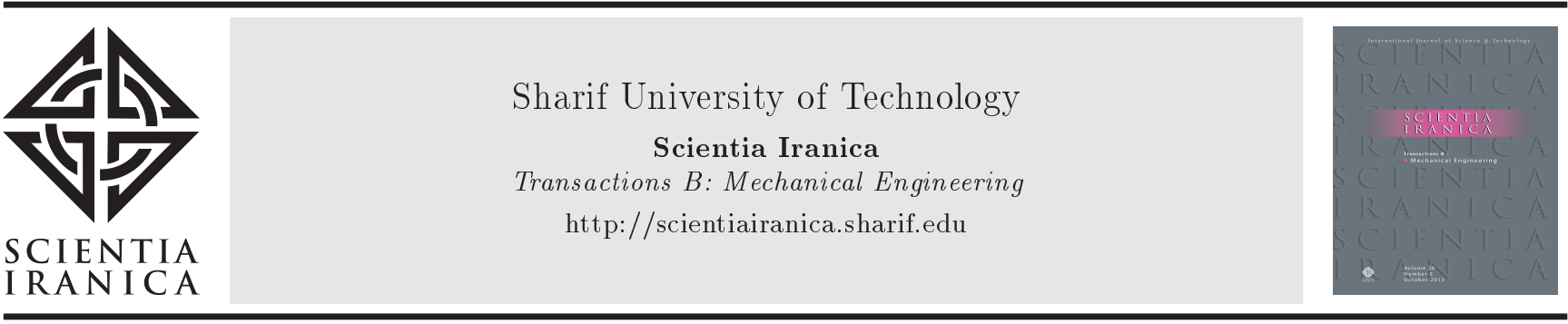

\title{
Agricultural tractors of the fifth generation
}

\author{
E.1. Lipkovich ${ }^{\mathrm{a}, *}$, A.Y. Nesmiyan ${ }^{\mathrm{b}}$, S.L. Nikitchenko ${ }^{\mathrm{c}}$, V.V. Shchirov ${ }^{\mathrm{d}}$, and \\ Y.G. Kormiltsev
}

a. Scientific Department, Azov-Black Sea Engineering Institute of Don State Agricultural University, 34 r7y 0 , 21 Lenin Str., Zernograd, Russian Federation.

b. Department of Technology and Mechanization of Agriculture, Azov-Black Sea Engineering Institute of Don State Agricultural University, 347740, 21 Lenin Str., Zernograd, Russian Federation.

c. Department of Technical Service in Agro-Industrial Complex, Azov-Black Sea Engineering Institute of Don State Agricultural University, 347740,21 Lenin Str., Zernograd, Russian Federation.

d. Engineering and Transfer Center, Azov-Black Sea Engineering Institute of Don State Agricultural University, 34 r74 40 , 1 Lenin Str., Zernograd, Russian Federation.

e. LLC "Research and Production Inculcation Firm 'Tenzor-T'", 347916, 11-49 Vishnevaya Str. Taganrog, Russian Federation.

Received 24 January 2018; accepted 9 October 2018

\section{KEYWORDS}

Machine-tractor unit; Mobile energy facility; Structural and analytical models; Stochastic process; Crop rotation; Mathematical expectation.

\begin{abstract}
In this study, the problem of substantiation of Mobile Power Units (MPUs)tractors for agriculture of the fifth generation-is described. The aim is to analyze agricultural tractors of the fifth generation. Technogenic interaction of MPUs with production processes in agro-ecosystems of grain production in the zonal conditions of arid agriculture in Southern Russia is described. Proposals for new MPUs are developed and the technological structures of machine aggregates based on the MPUs of the fifth generation of classes 3,5-6 and 8, to determine their technical schemes, are determined. Analytical models are provided for calculating the power characteristics of MPUs of the mentioned classes in deterministic and stochastic modes in relation to the most energyintensive operations with definitions of the mathematical expectations of Machine-Tractor Aggregate (MTA) power and performance. Effectiveness of MTAs is analyzed for the new MPUs based upon on the criterion of the time spent on cultivating crop rotations for classes 2 and 5-6 in wheeled and caterpillar performances and they are applied to the new generation of Machine-Tractor Station (MTS) of the technological services type. A comparison is carried out for the same sites with MTAs using the fourth-generation tractors. It will be observed that the time costs are reduced by $1.4-1.5$ times and for the MPU of class 8 , the reduction is up to 2.3 times.
\end{abstract}

(C) 2020 Sharif University of Technology. All rights reserved.

\section{Introduction}

For more than a century, the world's agriculture has been using agricultural tractors, which have been transformed from a simple primitive machine with

\footnotetext{
*. Corresponding author.

E-mail address: 4ye@mail.ru (E.l. Lipkovich)
}

doi: $10.24200 /$ sci. 2018.50339 .1643 steel wheels equipped with metal grippers and smallsized engines at a rate of 1.5 dozen hp. to robotic technical tools with excellent ergonomic conditions, space control of technological process, and Internal Combustion Engine (ICE) capacities 20 to 30 times that of the early models. This new modern machine has raised labor productivity at least 20 times.

However, one property of the modern tractors of both wheeled and caterpillar types has remained unchanged. In the aggregating agricultural machines with 
tractors, which have remained virtually unchanged, the tractor becomes a "steel horse" by its technological scheme, having one rear hook and a single rear hinged system. At the present time, the tractors are equipped with a multi-section, rather long train of successively working tools requiring a wide turning strip on the field being processed. Despite achieving the highest level of automation with increase in the number of operations in a single machine and tractor unit, the Machine-Tractor Aggregate (MTA) cumbersomeness consistently increases and, if anything, its technological reliability (also consistently) decreases.

In addition, the increased mass of the tractors, especially the wheeled ones, sharply worsens the ecological working conditions by increase in the specific pressure on the soil with a deep force effect on the arable and subsoil layers. The actual pressing of the soil along the wheel tracks and the relatively high slipping and grinding of soil aggregates attenuate the structure of the arable layer and contribute to the occurrence of wind erosion [1-3].

Therefore, it is required to find ways of improving the technological capabilities of modern tractors in order to increase the adequacy of mechanical and technological systems in the form of MTAs for production processes in agrocenoses.

The current problem in the development of mobile power engineering in the agroindustrial complex (AIC) is to find and justify the ways of optimal technogenic interaction of agricultural tractors with the technological MTAs developed based on them. The goal is to reduce the negative impact of running systems on the arable layer of the soil, decrease the intensity of erosion processes, and increase the reliability of multi-operation MTAs synthesized (collected) on the coupling devices.

\section{Materials and methods}

Different methods were used to achieve the set goal. Numerous studies in the Russian and the world agroengineering were analyzed to find the ways of reducing the harmful man-caused impact of mobile aggregates on the productive layer of soil. The results showed that one of the rational ways was organizing soil cultivation and cultivating field crops with a minimum number of drills along the processed field surface, while reducing the specific pressure from the impact of running systems. The necessity of reducing the impact on soil is unassailable. This requires, on the one hand, replacing the wheeled propellers of MPUs and technological rovers with caterpillars for cultivating, sowing, or harvesting the soil and, on the other hand, cutting the number of MTA passes through the field, which is still a difficult problem to resolve. The latter is unattainable to the full even with the capabilities of the modern tractors, no matter wheeled or caterpillar. It should be noted that in this paper, we consider heavy tractors of agricultural class 3 and above, which basically "make" the harvest of significant commodity producers. This applies to those Mobile Power Units (MPUs) that are still operating today, representing the fourth generation of mobile power engineering and having the technical structure developed at the dawn of their use (i.e., their technical structure, as noted above, has remained unchanged).

One more feature of the MTA composition should be noted, which is related to the rear trailing device or hinged system of the tractor. It is clear that a set of trailer machines ensures carrying out a multi-process complex operation in the expected positions (transitions), which can practically be performed within a single agro-term, simultaneously [4]. Multiprocessing aggregates are exactly aimed at reducing the number of passes through the field, which is the essence of public soil-saving measures. However, these aggregates are generally rather complicated, poorly controlled, and not flexible on the trajectory of motion when performing the technological process. The creation of multiprocessing tools and machines, e.g., the so called disk headers and the multi-purpose tillers for preparing soil in sowing winter crops on non-steam predecessors in Russia, seems to be an improvement to the process [5]. However, combined guns and their aggregates are rather cumbersome and heavy and they include several robot-like working elements in the unit, which are not connected geometrically by the sequence of operations. All the structural, technological, and organizational difficulties mentioned here have a common root: the imperfection of the engineering and technical structure of the fourth-generation tractors, which is also the case for the previous generations. This imperfection has gradually and consistently manifested itself and reached its peak at the present level of machine and technological support evolution.

In other words, in its development, the world's tractor equipment has lagged behind itself considering the fast-growing characteristics, fast-growing mass, the level of control systems, the ergonomic level $[6,7]$, the requirement of ecological balance of technogenic interaction with production agroecosystems, and finally the level of machine technologies for field crop production and the systems for organizing field work development. Once again, a certain imbalance has occurred in technology development. The huge growth and development of engineering has not resolved the organizational and technological issues that arise in the field of mobile energy [8].

The solution of the problem posed may lie in the ways of justifying and developing mobile energy resources in the fifth generation of machines-MPUs, not tractors-which have greater capabilities than the 
traditional tractors and are more sophisticated at the core components. However, it is inevitably achieved by considering and preserving all technological properties of the tractors of the fourth generation to retain the fundamental properties of modern tractors. Different generations of machines are distinguished based on their classes of thrust and, correspondingly, massenergy characteristics $[9,10]$. Therefore, the fifth generation of MPUs can confidently be aggregated with the same tools and machines as those of the fourth generation of tractors, but with various functional or multifunctional MTAs.

\section{Results and discussion}

Machine-tractor units with MPUs of the fifth generation are directly synthesized for field work in zonal rotations on a multifunctional, multiprocess basis, i.e., with the potential of performing several technological operations that have the same agro-term or can be technologically carried out in a single agro-term. This reduces the total number of operations and the number of passes of heavy equipment on the plow layer. On the other hand, considering the significant increase in the use of tracked propellers, which were originally implemented in the system of tractors for agriculture, including in the US, the structure of the MPU of the fifth generation gets closer to realizing the requirements of ecological balance of technogenic processes of agrocenosis production [3,11-13].

In fact, agrocenoses, implemented by zonal crop rotations or operations of technological services in agricultural organizations, Agricultural Product Companies (APCs), and peasant farms as the most laborintensive institutions with large volumes of production, directly set the agrotechnological structure of MTA, the derivatives of which are MPUs of different classes $[10,14,15]$.

The structure of MPU of the fifth generation, in order to ensure a rational synthesis of technological MTAs in zonal rotations and service and technological work, should include the following features (the preliminaries):

- Presence of 2 universal hinged systems, front and rear;

- Presence of 2 independent unified shafts of power take-off, front and rear, providing up to 80 to $85 \%$ energy transfer of rotary motion to power-driven machines mounted on the front or rear attachment system or traction device;

- Stepless drive of the undercarriage, hydraulic or electric (in this paper, we consider MPU of the fifth generation with a stepless hydrostatic drive, which has been sufficiently developed and successfully used for a long time in the world agricultural machinery);
- Wheeled MPUs of classes 3 and 5-6 equipped with an easy-shift caterpillar chassis; MPUs in wheel designs weighing more than $11.000 \mathrm{~kg}$, based on numerous studies conducted in a long period of time as well as long-term observations, should fall into disuse in field work.

We have chosen, so to speak, the following field work of new MPUs:

- South-Russian grain-fodder crop rotation in arid agriculture by the use of black steam in the peasant farms, eight fields, with an area of 960 ha (farmer rotation);

- A large crop rotation in the same grain-fodder area, nine fields, with 2.250 hectares for agricultural organizations (APC, CAE, etc.) by the use of black steam;

- A set of labor-intensive field work in the form of technological service for surface tillage (400 ha), subsoiling and other heavy surface tillage operations (3.500 hectares), harvesting of cereals (1.200 ha), and maize for silage (800 ha).

Operations on these volumes of work set the technical structure of the MPUs of the three classes we are developing, namely 3, 5-6, and 8, which are the main machines that "make" the harvest [10].

In Figure 1, the general layout of MPU-3200 of class 3 with power of $184 \mathrm{~kW}$ in wheel (a) and caterpillar (b) variants by the use of a replaceable running gear is shown. The MPUs are equipped with MTA for processing the mentioned farmer crop rotation, with the exception of the spiked cereals harvesting process, which is performed by a self-propelled combine harvester (of medium or even small class).

The second crop rotation is processed by a complex of machines based on the caterpillar MPU-5400 of class 5 with power of 260 to $280 \mathrm{~kW}$ (Figure 2). It provides all the necessary acquisition of MTA, including the process of harvesting spiked cereals by a trailed non-motorized combine (Figure 3 ).

Figure 4 shows the schematics of fodder-soilcultivating MTA on the basis of caterpillar MPU5400. The MTA is equipped with a trailing implement AKM-4 (6) to prepare the soil for sowing winter crops on non-steam predecessors (multi-process MTA), simultaneously, by harvesting maize for silage.

Figure 5 shows the physical model of MPU-5400 (scale 1:12) with two mounted tillage tools: disk (on the front) and a deep scraper (on the rear).

Finally, MTAs, equipped with a caterpillar MPU8470 of class 8 with power of up to $380 \mathrm{~kW}$ (Figures 6 and 7 ) are used in service technological operations. At the same time, MPU of class 8 performs all harvesting operations, including harvesting of spiked cereal crops 

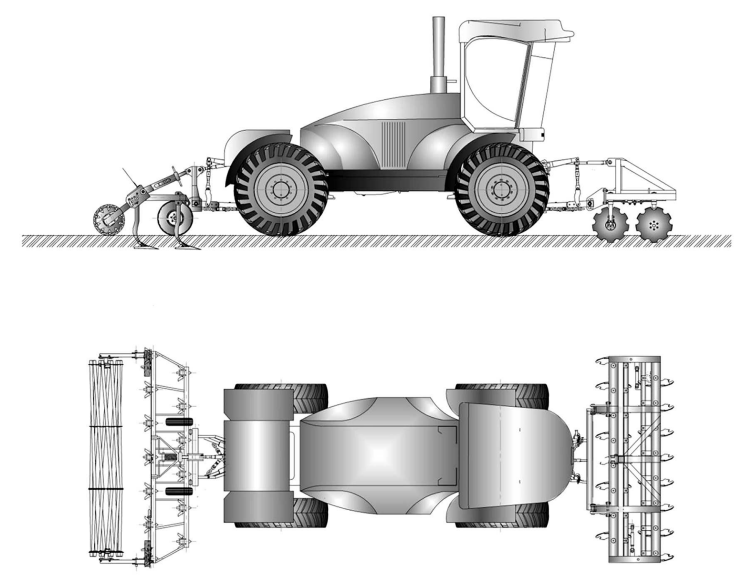

a) For nonmoldboard basic soil tillage
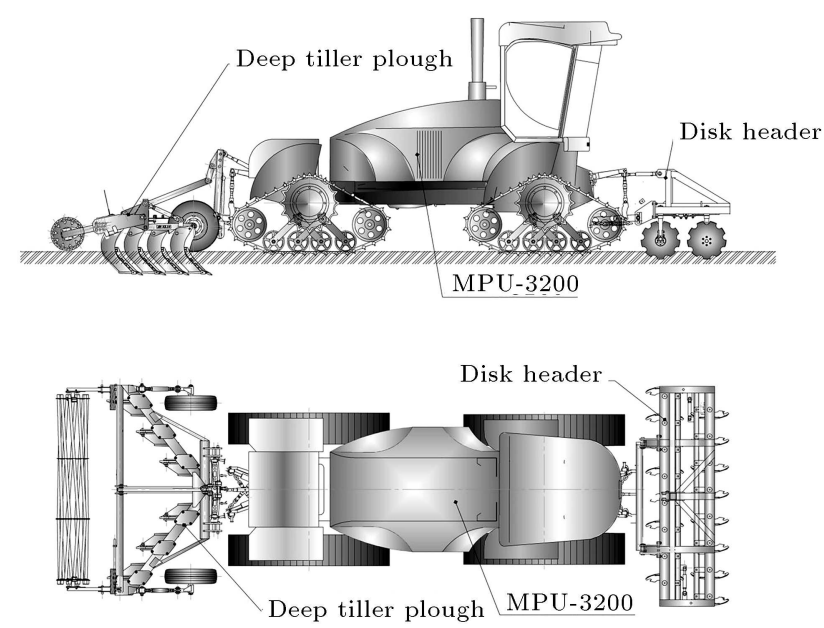

b) In caterpillar performance (changeable chassis)

Figure 1. Mobile power unit MPU-3200 of cl. 3 with power of $180 \mathrm{~kW}$.

using a trailed, non-motor, high-performance combine harvester (Figure 8).

Synthesized MTAs for all three uses of MPU-3200, MPU-5400, and MPU-8470 with mounted machines and implements are given in Table 1.

In justifying and calculating the MPU transmission, it is of particular interest to determine the energy characteristics combining mechanic, analytic, and hydrodynamic constructions in both deterministic and probabilistic executions.

Let us consider the hardest working conditions of MPU in the traction and drive modes, when the MTA on the basis of MPU not only performs operations with trailed and mounted implements, but also threshes spiked cereals with a trailed non-motorized combine harvester or harvests corn for silage using a mounted adapter.

We will write the determined ratio of energy consumption in the expanded form for MTA on the
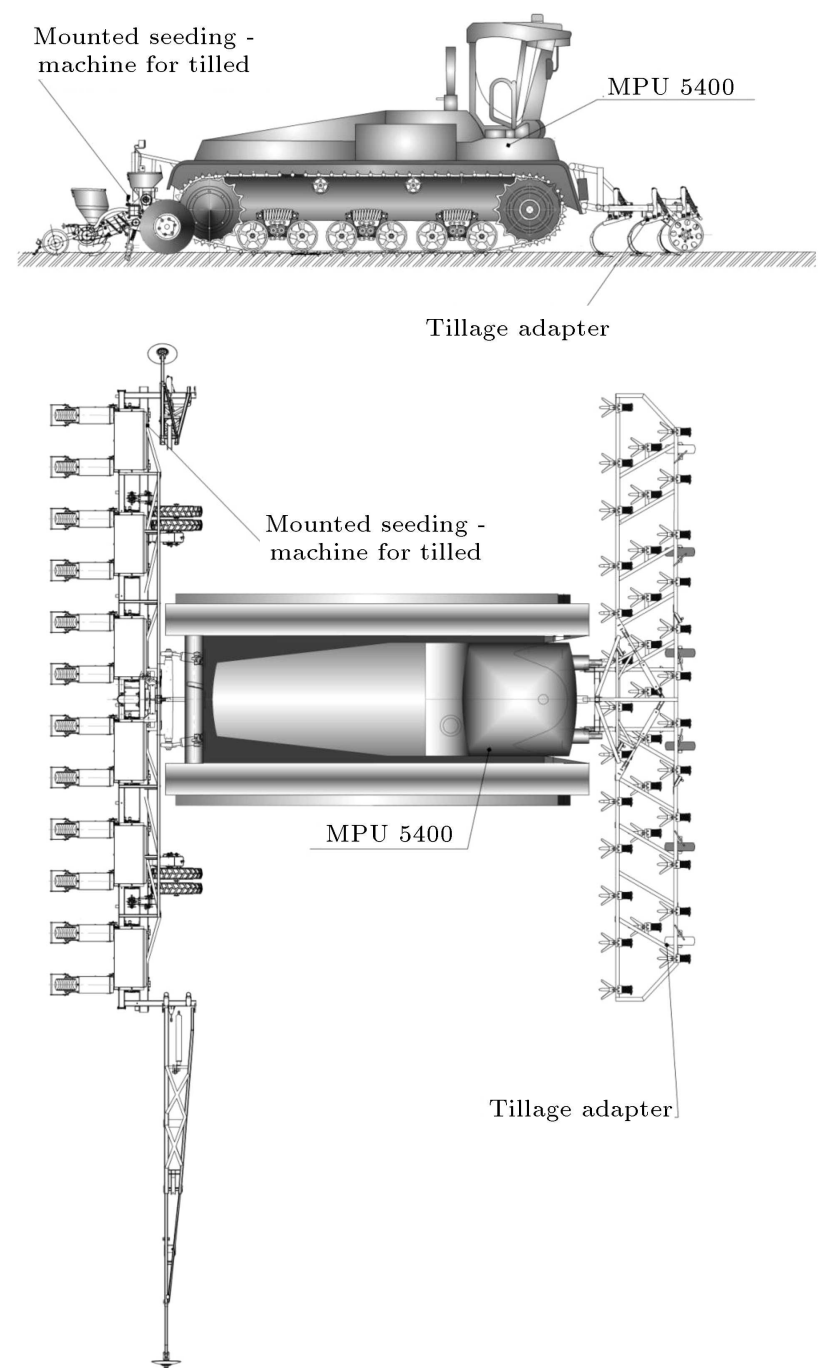

Figure 2. Mobile power unit MPU-5400 of cl. 5 with power of $280 \mathrm{~kW}$ with mounted tools.

basis of MPU-5400 (Eq. (1)):

$$
\begin{aligned}
N_{\text {eff }}= & \Delta p_{21} B_{21} \cdot \frac{\vartheta_{\text {mov }}}{75}+m_{5400} \cdot f_{\text {roll }} \cdot \frac{\vartheta_{\text {mov }}}{75} \\
& +m_{\text {harv }} \cdot f_{\text {roll }} \\
& +\Delta p_{\text {harv }} \cdot \frac{\vartheta_{\text {mov }}}{75}+m_{\text {corn }} \cdot f_{\text {roll }} \cdot \frac{\vartheta_{\text {mov }}}{75} \cdot \frac{\vartheta_{\text {mov }}}{75} .
\end{aligned}
$$

Here, $N_{\text {eff }}$ is the effective power providing the operation of the MTA. If we take the whole of the right side of Eq. (1) as the energy resistance $N_{t m r}$, then $N_{\text {eff }} \geq$ $N_{t m r}$. The first term on the right side corresponds to energy resistance of the disk header with width $B_{21}$ (it is the same for all working elements), which moves with the translational velocity, $\vartheta_{\text {mov }}$ (it is the same for all MTAs). $\Delta_{p 21}$ is specific resistance of the disk header $(\mathrm{kgf} / \mathrm{m})$.

The second additive determines the resistance of the MPU-5400 mass to rolling $\left(m_{5400}\right.$ is the operational 


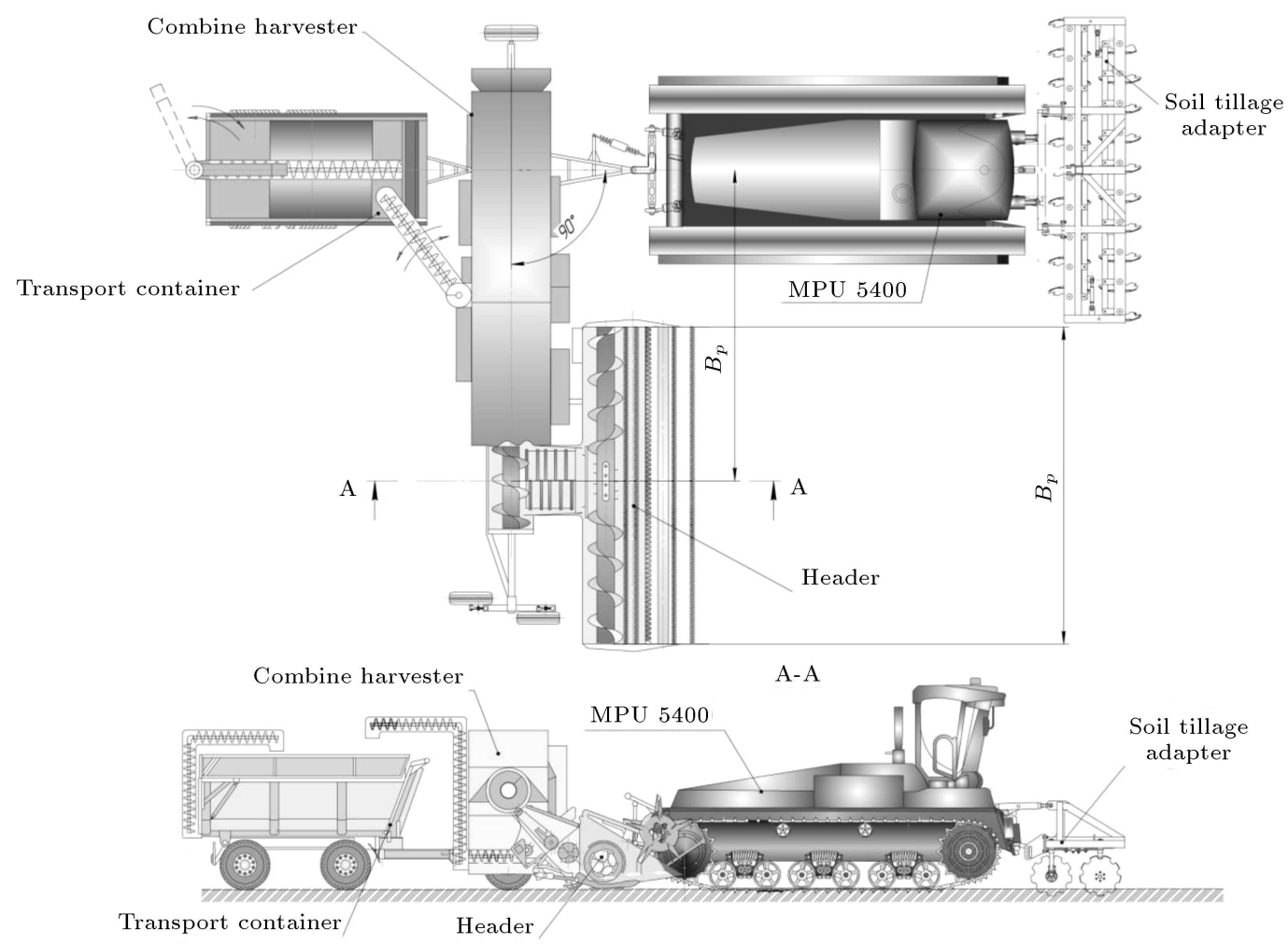

Figure 3. Grain-harvesting and soil-cultivating MTAs on the basis of MPU-5400: the mounted adapter for post-harvest closing of moisture; trailed non-motor combine by axial-rotary with the capacity of 5 to $6 \mathrm{~kg} / \mathrm{s}$ by means of a transverse arrangement of threshing-separating devices; tank grain trailer.

mass of the energy source; $f_{\text {roll }_{t r}}$ represents the rolling factor of the track-type machine; and $f_{\text {roll }_{t r}}=0.08$ ) and the third additive reflects the cost of energy for rolling the total operating weight of a non-motor combine $\left(m_{\text {harv }}\right.$ is mass of the combine; $f_{\text {roll }}$ stands for rolling ratio; and $f_{\text {roll }_{t r}}=0.12$ ). The fourth additive corresponds to the amount of energy spent on rolling the mass of grain $m_{\text {corn }}$ in the trailer bunker and the last additive estimates the energy input to the technological process of the combine itself, the value of which depends on the yield of the plant mass. Its per-second feed $q(\mathrm{~kg} / \mathrm{s})$ into the grinder at the corresponding translational speed, $\vartheta_{\text {mov }}$, can be calculated on the basis of the value of the specific energy consumption for threshing, which we estimate to be equal to $17 \frac{\mathrm{kW}}{\mathrm{kg} / \mathrm{s}}$ under the given conditions.

Also, $N_{t m r}$, after the substitutions and calculations, will be $190.7 \mathrm{~kW}$.

Now, let us introduce the hydraulic drive, keeping in mind that the moment $M_{\text {eff }}$, created by the hydraulic drive to supply energy to MPU-5400 for all its mounted, trailed, and driven machines and implements, obeys the relation $M_{\text {eff }} \geq M_{t r m}$, where $M_{t r m}$ is the total moment of resistance (Eq. (2)):

$$
M_{e f f}=\frac{N_{e f f} \cdot 9449}{n_{g m}}=\frac{190.7 \cdot 9449}{1900}=948.4 \mathrm{~N} \cdot \mathrm{m} .
$$

Eq. (2) corresponds to hydrodynamic regularities [16]). $n_{g m}$ is frequency of rotation of the ICE shaft, to which the value of frequency of rotation of the drive motor is given.

The value of $M_{e f f}$, developed by the hydraulic drive, will be (Eq. (3)):

$$
M_{e f f}=\frac{1.56 \cdot \vartheta_{g m} \cdot \Delta \cdot \eta_{m h}}{100} .
$$

Therefore, we have:

$$
\vartheta_{g p}=\frac{948.4 \cdot 100}{1.56 \cdot 350 \cdot 0.95}=182.8 \mathrm{sm}^{3} .
$$

At $\Delta p=350 \mathrm{kgf} / \mathrm{sm}^{2}$, the flow rate $Q$ of the working fluid in accordance with [16] is (Eq. (5)):

$$
Q=\frac{\vartheta_{g m} \cdot n_{g m}}{1000 \cdot \eta_{m h}}=\frac{182.8 \cdot 1900}{1000 \cdot 0.95}=365.6 \mathrm{l} / \mathrm{min} .
$$

Accordingly, $N_{t p}$, the total power consumed by the hydraulic drive, will amount to (Eq. (6)):

$$
N_{t p}=\frac{Q \cdot \Delta p}{612 \cdot \eta}=\frac{365.6 \cdot 350}{612 \cdot 0.9}=232.3 \mathrm{~kW} .
$$

Finally, we determine the mathematical expectation of the drive (consumed power [17] based on the calculations of analytical constructions by Prof. L.Ye. Ageyev (Eqs. (7)-(9)): 


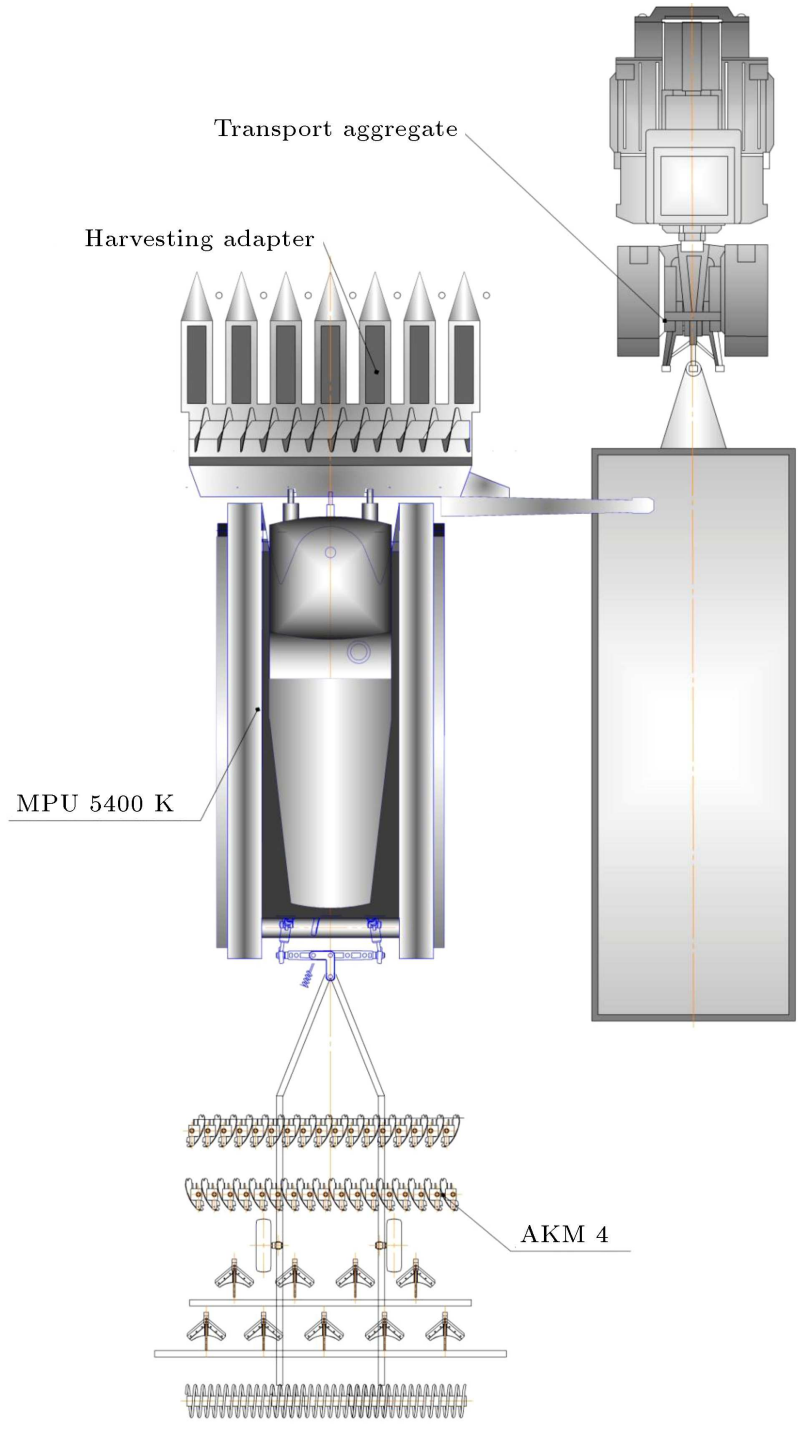

Figure 4. Forage-soil cultivating MTA on the basis of wheel MPU-5400 of class 5: mounted silage harvester for harvesting and chopping maize for silage; AKM aggregate for soil preparation for sowing of winter crops on non-steam trailed predecessor.

$$
\begin{aligned}
& N_{e_{\max }}=\bar{N}_{e}+3 \sigma_{N_{e}}, \\
& N_{e_{\min }}=\bar{N}_{e}-3 \sigma_{N_{e}},
\end{aligned}
$$

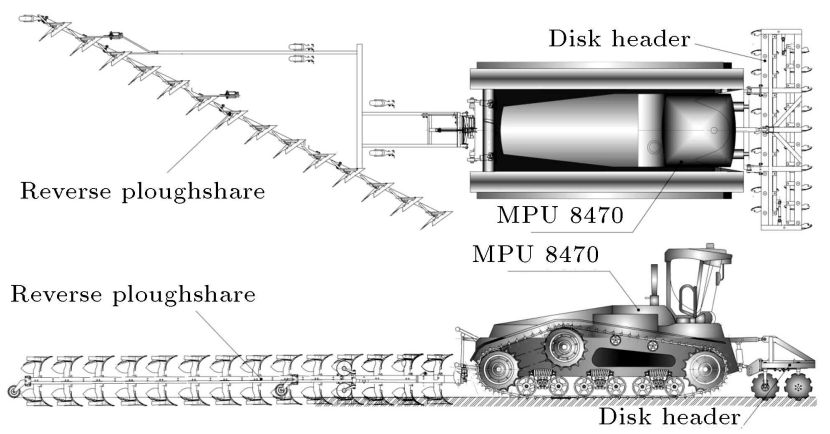

Figure 6. Mobile power unit MPU-8470 of class 8 with power of $380 \mathrm{~kW}$ with trailed 12-hull reverse plow and hinged disk header for post-harvest moisture closure in the production layer of the soil.

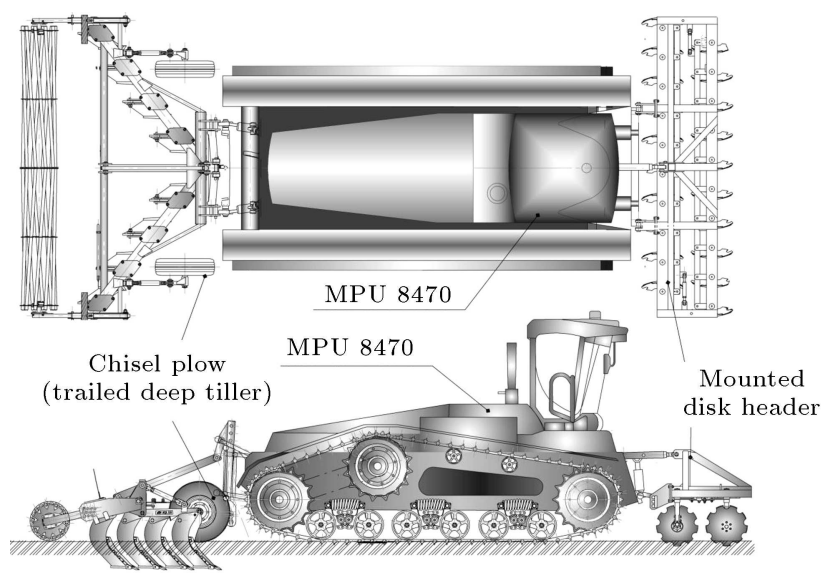

Figure 7. Mobile power unit MPU-8470 with mounted disk header and trailed deep tiller (chisel plow).

$$
\lambda_{\bar{N}}=\frac{M\left(N_{e}\right)}{N_{e}} .
$$

Hence, the mathematical expectation $M\left(N_{e}\right)$ of the power will be (Eq. (10)):

$$
M\left(N_{e}\right)=\lambda_{\bar{N}} \cdot N_{e}
$$

Here, $\lambda_{\bar{N}}=0.89$ (the degree of ICE loading) at $\sigma_{N_{e}}=$ $\frac{232.3 \cdot 0.2}{3} 15.5 \mathrm{~kW}$. Then Eq. (11) is obtained:

$$
N_{t p}=M\left(N_{e}\right)=232.3 \cdot 0.89+3 \sigma_{N_{e}}=252 \mathrm{~kW} .
$$

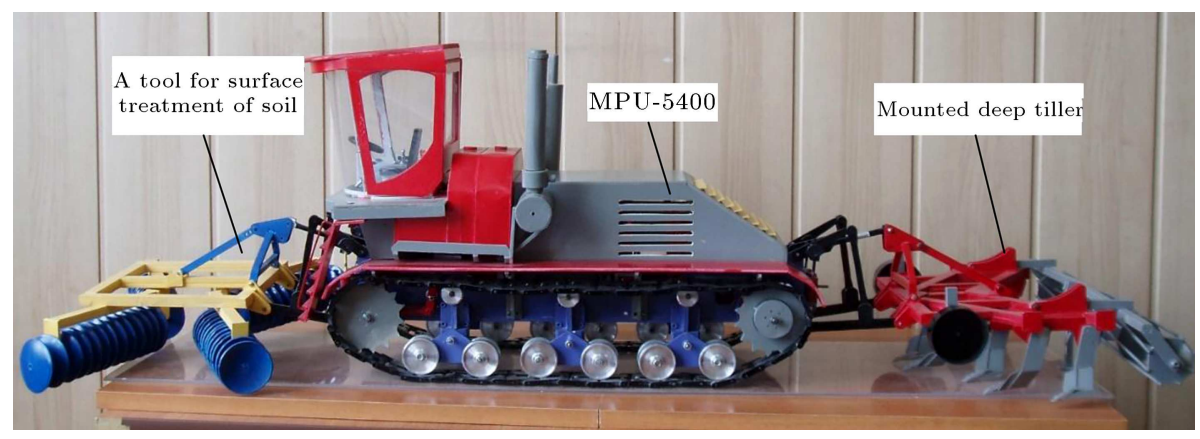

Figure 5. Tillage caterpillar MTA; MPU of class 5 (model in scale 1:12). 

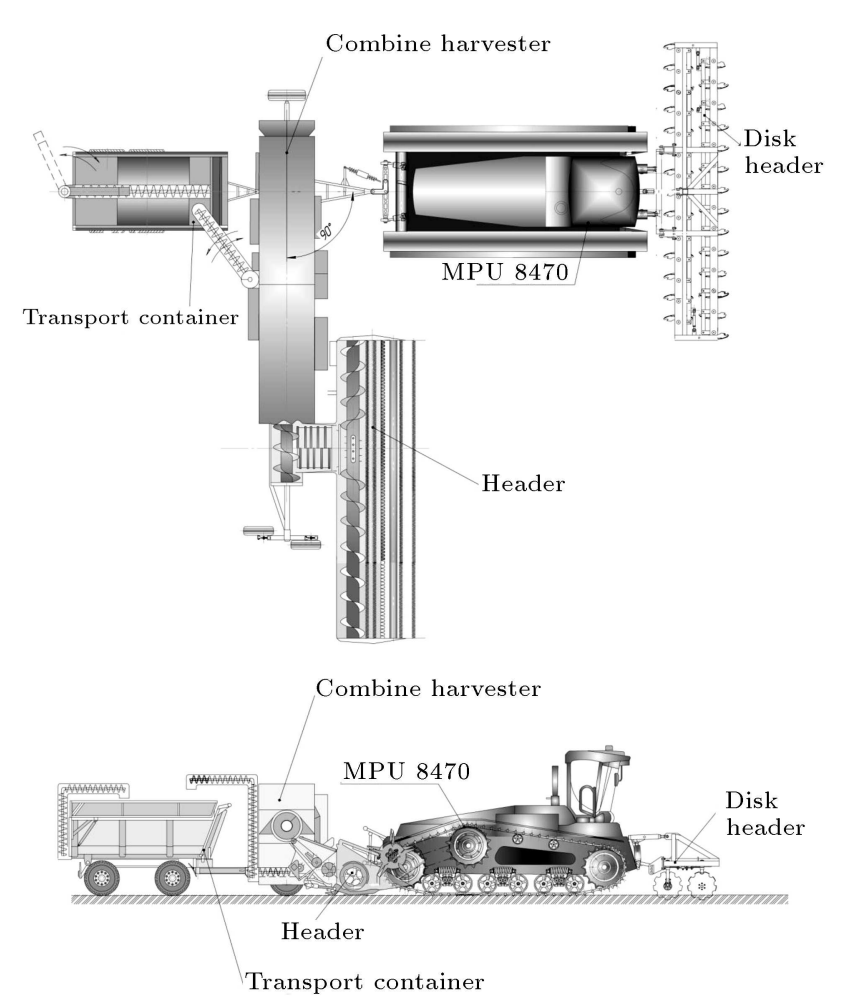

Figure 8. MPU-8470 with a trailed high-performance, non-motorized combine harvester by means of a transverse axial-rotor threshing separating device with a throughput capacity of 8 to $8.5 \mathrm{~kg} / \mathrm{s}$ with a trailer hopper and a disk header to cover moisture.

We take the power of the installed ICE as $265 \mathrm{~kW}$ (or 360 hp.).

In this way, the power of the ICE in the MPU5400 drive and other new types of MPUs with a hydraulic drive is calculated. According to the data obtained, it is already possible to perform a detailed calculation of the hydrostatic transmission and engage in the design of the hydraulic drive as a whole.

The economic efficiency of the use of new MPUs (of the fifth generation) has been calculated in relation to those conditions that are determined by the operational platforms using the methodologies of VNIPTIMESKH and ACHII. All the new MPUs participating in the technological processes are equipped with working bodies, machines, and tools forming multiprocess MTAs (as presented in Table 1 with reference to MPU-3200, MPU-5400, and MPU-8470).

As a basis for comparison, traditional technologies and MTAs based on tractors of the fourth generation are used for the first variant (crop rotation applied to the PF area of 960 hectares) in the new ATM3180 wheeled tractor (class $3,132 \mathrm{~kW}$ ). For the second variant (crop rotation of 2250 hectares for agricultural organizations), on the basis of a new crawler tractor of class 6, named "Ruslan," with a capacity of $246 \mathrm{~kW}$. The third item is for service technological operations by the same "Ruslan," because it is the most powerful agricultural tractor in Russia. By considering the duration of the original work as the evaluation criterion at the MTA synthesis stage, the effectiveness evaluations are first carried out in accordance with the criteria for the type of discounted income in this study.

The calculated data for the third variant (as an example) are given in Table 2 .

Table 2 shows that the number of working hours for four operations performed by multi-process MTAs based on the MPU-8470 is 1402.3. The traditional MTAs based on the fourth-generation caterpillar tractor performed the same work in six operations spending 3229.1 hours. It can be concluded that the new complex of machines, combined into multiprocess MTAs based on MPU-8470, ensures 2.3 times reduction in the duration of work, proving high technical and operational efficiency of the innovative technology and equipment. Appropriate, though not so high, indicators have been obtained for two other innovative machine complexes. Multiprocess MTAs based on MPU3200 in wheeled and, in some operations, caterpillar performances (with replaceable running gear) reduce the estimated duration of original operations to $831.7 \mathrm{~h}$, against $1143.8 \mathrm{~h}$ by traditional technology based on the fourth-generation-tractor ATM-3180, i.e., 1.38 times.

The second variant, which is analyzed using the fifth-generation MPU-5400 MPU in innovative MTAs, leads to the total duration of 1408.5 hours for multiprocessing operations, reducing it compared to the traditional technology based on the fourth-generation Ruslan tractor with 2155.2 h, i.e., 1.53 times.

Thus, it can be concluded that in the mass work in agricultural production, labor costs from the use of innovative MTAs based on the MPU of the fifth generation will be reduced by 1.3 to 1.5 times. In general, this is a fairly significant reduction in labor costs.

The values of the mathematical expectation of the hourly performance of $M(W)$ multiprocess MTAs based on MPU of the fifth generation are determined by the dependence relation (Eqs. (12) and (13)):

$$
M(W)=c_{1} M\left(N_{e}\right)
$$

where

$$
c_{1}=0,36 \eta_{m} \tau \frac{1}{k_{a}}
$$

where $\eta_{m}$ is the tractive efficiency, $\tau$ is the degree of use of the operating time of the MTA, and $1 / k_{a}$ is the specific resistance of MTA in $\mathrm{kN} / \mathrm{m}$. Table 3 shows the values of $M(W)$ for the three MPU classes considered for $\eta=0.6, \tau=0.7$, and $1 / k_{a}=11 \ldots 13.3 \mathrm{~kW} / \mathrm{T}$.

The proposed mobile energy of the fifth generation for agriculture has a much greater potential for 
Table 1. Complex operations and composition of multi-process Machine-Tractor Aggregates (MTA) based on Mobile Power Units (MPU) of the fifth generation.

\begin{tabular}{|c|c|c|c|c|c|}
\hline \multicolumn{2}{|c|}{$\begin{array}{l}\text { Crop rotation of } \\
960 \text { ha }(\mathrm{PF})\end{array}$} & \multicolumn{2}{|c|}{$\begin{array}{l}\text { Crop rotation of } 2250 \text { ha } \\
(\mathrm{AS}, \mathrm{CAE}, \mathrm{APC})\end{array}$} & \multicolumn{2}{|c|}{$\begin{array}{c}\text { Technological service of } \\
\text { MTS type }\end{array}$} \\
\hline $\begin{array}{l}\text { Name of } \\
\text { operation }\end{array}$ & $\begin{array}{l}\text { MTA } \\
\text { composition: } \\
\text { MPU-3200 }\end{array}$ & $\begin{array}{l}\text { Name of } \\
\text { operation }\end{array}$ & $\begin{array}{l}\text { MTA } \\
\text { composition: } \\
\text { MPU-5400 }\end{array}$ & $\begin{array}{l}\text { Name of } \\
\text { operation }\end{array}$ & $\begin{array}{l}\text { MTA } \\
\text { composition: } \\
\text { MPU- } 8470\end{array}$ \\
\hline $\begin{array}{l}\text { Pre-sowing tillage } \\
\text { with sowing of } \\
\text { spiked cereals }\end{array}$ & $\begin{array}{l}\text { Mounted cultivator } \\
+ \text { MPU caterpillar } \\
\text { variant + sowing } \\
\text { complex-coupling }\end{array}$ & $\begin{array}{l}\text { Harvesting } \\
\text { winter crops } \\
\text { with primary } \\
\text { field processing }\end{array}$ & $\begin{array}{l}\text { Harrow disk } \\
\text { medium }+ \\
\text { MPU-5400 }+ \\
\text { harvester trailed } \\
\text { non-motorized }\end{array}$ & $\begin{array}{l}\text { Surface tillage }+ \\
\text { subsoiling }\end{array}$ & $\begin{array}{l}\text { Harrow medium } \\
+\mathrm{MPU}+\text { deep } \\
\text { tiller }\end{array}$ \\
\hline $\begin{array}{l}\text { Pre-sowing tillage } \\
\text { with simultaneous } \\
\text { sowing of tilled }\end{array}$ & $\begin{array}{l}\text { Mounted cultivator } \\
+ \text { MPU wheel variant } \\
+ \text { tilled mounted } \\
\text { seeding-machine } 8 \mathrm{~m}\end{array}$ & $\begin{array}{l}\text { Soil preparation } \\
\text { for sowing with } \\
\text { corn sowing }\end{array}$ & $\begin{array}{l}\text { Cultivator } \\
+ \text { MPU + tilled } \\
\text { mounted seeding-machine }\end{array}$ & $\begin{array}{l}\text { Subsoiling with } \\
\text { soil leveling }\end{array}$ & $\begin{array}{l}\text { Disk header }+ \\
\text { MPU + deep } \\
\text { tiller }\end{array}$ \\
\hline $\begin{array}{l}\text { Harvesting of } \\
\text { corn for silage } \\
\text { with preparation } \\
\text { of soil for sowing } \\
\text { of winter crops }\end{array}$ & $\begin{array}{l}\text { Mounted forage } \\
\text { harvester adapter } \\
\text { + MPU wheel + AKM-4 }\end{array}$ & $\begin{array}{l}\text { Harvesting of corn } \\
\text { in cobs with } \\
\text { preparation of soil } \\
\text { for sowing of winter } \\
\text { crops (according to } \\
\text { non-steam predecessors) }\end{array}$ & $\begin{array}{l}\text { Adapter cob } \\
\text { sweeper mounted } \\
+ \text { MPU }+ \\
\text { AKM-4 }\end{array}$ & $\begin{array}{l}\text { Cultivation } \\
\text { without waste } \\
\text { treatment }\end{array}$ & $\begin{array}{l}\text { Cultivator } \\
+\mathrm{MPU}+\mathrm{AKM}-8\end{array}$ \\
\hline $\begin{array}{l}\text { Dump plowing } \\
\text { - basic sow tillage }\end{array}$ & $\begin{array}{l}\text { Mounted disk } \\
\text { header + caterpillar } \\
\text { MPU + mounted } \\
\text { plow six-hull } \\
2.1 \mathrm{~m}\end{array}$ & $\begin{array}{l}\text { Harvesting of } \\
\text { peas from the } \\
\text { rolls with } \\
\text { preparation of } \\
\text { soil for sowing } \\
\text { winter crops } \\
\text { (by non-steam } \\
\text { predecessors) }\end{array}$ & $\begin{array}{l}\text { AKM-6 + MPU } \\
+ \text { harvester trailed }\end{array}$ & $\begin{array}{l}\text { Primary soil } \\
\text { tillage with } \\
\text { leveling }\end{array}$ & $\begin{array}{l}\text { Disk header } \\
+ \text { MPU }+ \\
\text { reversible } \\
\text { plow 12-hull }\end{array}$ \\
\hline $\begin{array}{l}\text { Preparation of } \\
\text { soil for } \\
\text { sowing with } \\
\text { subsoiling }\end{array}$ & $\begin{array}{l}\text { Mounted disk } \\
\text { header on the } \\
\text { front attachment } \\
+ \text { MPU caterpillar } \\
\text { version + mounted } \\
\text { deep tiller }\end{array}$ & $\begin{array}{l}\text { Cleaning of } \\
\text { winter crops } \\
\text { with primary } \\
\text { soil treatment }\end{array}$ & $\begin{array}{l}\text { Harrow medium } \\
+\mathrm{MPU}+ \\
\text { harvester trailed }\end{array}$ & $\begin{array}{l}\text { Harvesting of } \\
\text { spiked cereals } \\
\text { with comber }\end{array}$ & $\begin{array}{l}\text { Combing } \\
\text { adapter }+\mathrm{MPU} \\
+ \text { mounted MSU } \\
\text { with cleaning } \\
+ \text { towed trailer }\end{array}$ \\
\hline- & - & $\begin{array}{l}\text { Harvesting of corn } \\
\text { for silage with } \\
\text { preparation of } \\
\text { soil for sowing } \\
\text { of winter crops } \\
\text { (for non-steam } \\
\text { predecessors) }\end{array}$ & $\begin{array}{l}\text { Mounted feed-harvesting } \\
\text { adapter (for } \\
\text { front hitch) } \\
\text { + MPU + AKM- } 6\end{array}$ & $\begin{array}{l}\text { Mowing of corn } \\
\text { for silage with } \\
\text { preparation of } \\
\text { soil for sowing } \\
\text { of winter crops }\end{array}$ & $\begin{array}{l}\text { Feed- } \\
\text { harvesting } \\
\text { adapter }+ \\
\text { MPU + AKM-8A }\end{array}$ \\
\hline
\end{tabular}

reducing the time required to implement technological processes in the cultivation of field crops. Real ways of ecological balance of technogenic processes in grain production are identified, which include reduction in the number of driveways across the field by the creation of multiprocess MTAs and use of a replacement chassis. It is beyond doubt that adapting the existing agricultural tractors of the fourth generation for multiprocessing operations, for example, by a set of a line loop of tools and machines, is extremely inconvenient in operation with simultaneous loss of productivity. However, by the development of special machines of a new generation, 
Table 2. Technical and operational indicators on labor-intensive and complex technological operations of traditional and innovative Machine-Tractor Aggregates (MTA) based on Mobile Power Unit (MPU) of class 8.

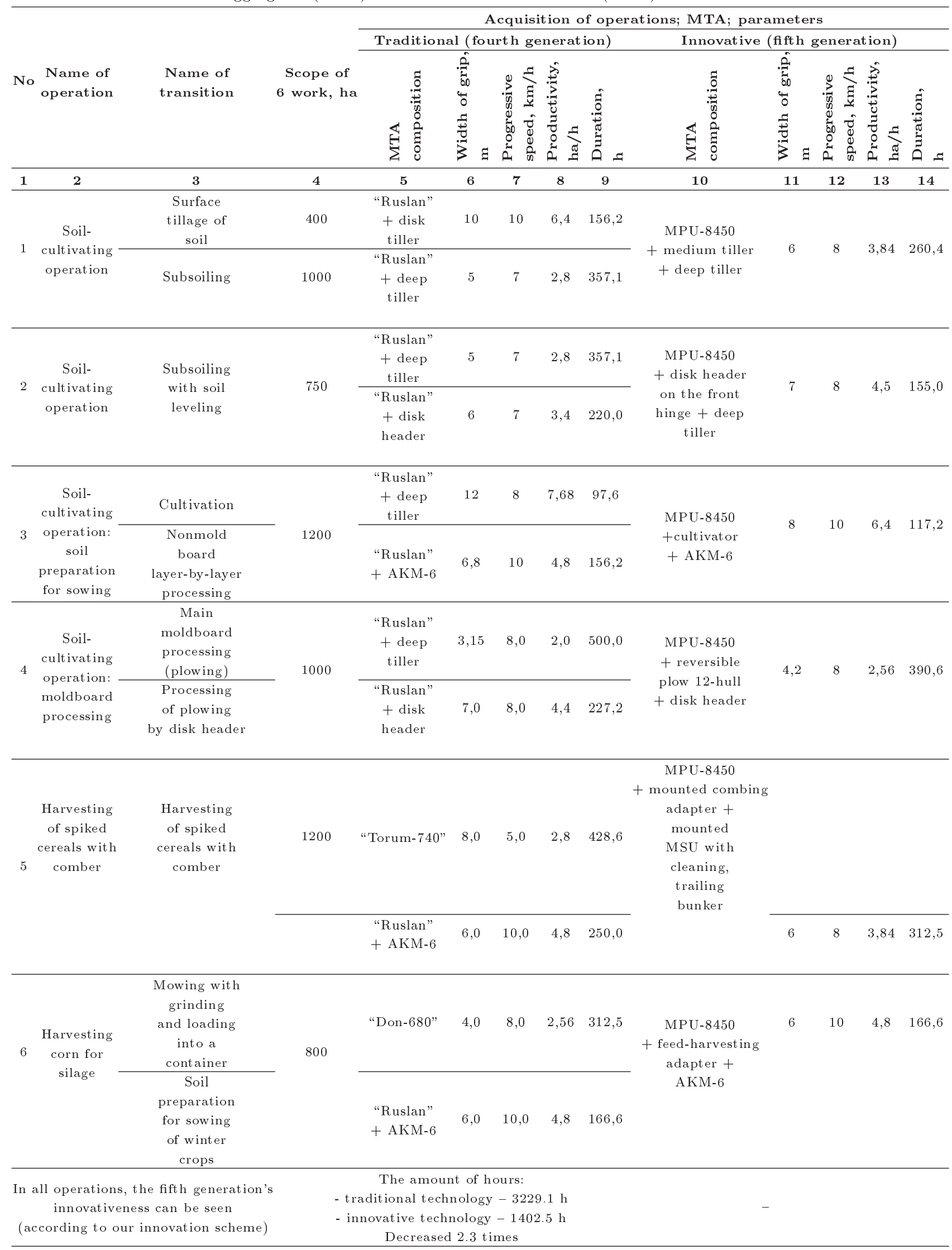


Table 3. Mathematical expectations of the hourly performance of multiprocess Machine-Tractor Aggregates (MTAs) based on the fifth-generation MPU.

\begin{tabular}{cccccc}
\hline $\begin{array}{c}\text { MPU: } \\
\text { Conventional } \\
\text { brand }\end{array}$ & \multicolumn{6}{c}{ Meanings } \\
\cline { 2 - 6 } & & \multicolumn{1}{c}{$\boldsymbol{\eta}_{\boldsymbol{m}}$} & $\boldsymbol{k}_{\boldsymbol{a}}, \mathbf{k W} / \mathbf{t}$ & $\boldsymbol{M}\left(\boldsymbol{N}_{\boldsymbol{e}}\right), \mathbf{k W}$ & $\boldsymbol{M}\left(\boldsymbol{W}_{\boldsymbol{u}}\right), \mathbf{h a} \mathbf{h}$ \\
\hline MPU-3200 & & 0.6 & 11.0 & 169.0 & 2.3 \\
MPU-5400 & 0.7 & & 12.0 & 252.0 & 3.17 \\
MPU-8470 & & 0.65 & 13.3 & 320.0 & 3.94 \\
\hline
\end{tabular}

synthesis of mobile aggregates can be carried out quite comfortably and they can "genetically" be adapted for multi-process operations. At the same time, a radical modernization of transmissions in the direction of steplessness is envisaged and there is no limit on the wide opportunities for MTA automation. This problem could have been solved in the fourth-generation tractors much earlier, given that one of the authors of this work participated in creating a prototype of a real fifth-generation class three MPU with a hydrodrive 30 years ago.

The same applies to the replacement caterpillar chassis, which was created in the b. VNIPTIMESKH (Zernograd) also about 30 years ago. Nevertheless, now, the problem has shifted to the real plane of its solution and the technical documentation for the fifthgeneration MPU is being developed.

\section{Conclusions}

Modern tractors of the fourth generation have reached such a high power to weight ratio in their development that their loading requires synthesis of rather bulky trailed and mounted complex structures, which reduces productivity to some extent. Heavy energy resources have a negative impact on the soil, contribute to a significant decrease in yield, worsen the structure of the arable layer, destroy soil aggregates, and lead to more wind erosion.

A family of (MPUs) of the of classes 3, 56 , and 8 was developed with a power from 180 to $350 \mathrm{~kW}$ and weight from 7600 to $14500 \mathrm{~kg}$. They were equipped with two unified mounted systems, two independent PTOs, a stepless drive transmission, and a replaceable caterpillar chassis. The so-called multiprocess Machine-Tractor Aggregates (MTA) could be synthesized based on them to ensure the ecological balance of the technogenic interaction of the MTA with the production layer in agroecosystems and reduce the duration of field operations both in individual processes and in zonal rotation as a whole.

The use of stepless transmission allowed for utilizing full power of the MPU energy unit at any point of the MTA's trajectory to the max and opened up wide possibilities for automation of dynamic systems in order to increase the stability of the output parameters of technological processes.

The use of the light-weight crawler tracker on MPUs of classes 3 and 5 with a mass not more than $11.000 \mathrm{~kg}$, by the simultaneous removal of machines with larger masses in the wheeled version from field work, effectively resolved the problem of negative manmade impact on the production layers of the soil.

Carrying out design and calculation work for the creation of a fifth-generation MPU with stepless hydraulic drive of the transmission to improve accuracy implied the introduction of hydrodynamic regularities and the apparatus of random functions into the computational algorithms.

\section{References}

1. De Farias, M.S., Schlosser, J.F., Bertollo, G.M., Martini, A.T., and De Oliveira, L.F.V. "Energy efficiency of an agricultural tractor according to different driving modes and working speeds", Sientifica, 46(2), pp. 101106 (2018).

2. Ramaswami, B., Ravi, S., and Chopra, S.D. Risk Management in Agriculture Indian Statistical Institute, Planning Unit, pp. 3-8 (2005).

3. Brouwer, F.M. and van Ittersum, M., Environmental and Agricultural Modelling: Integrated Approaches for Policy Impact Assessment, Springer (2010).

4. Cavallo, E., Ferrari, E., and Coccia, M. "Likely technological trajectories in agricultural tractors by analysing innovative attitudes of farmers", International Journal of Technology, Policy and Management, 15(2), pp. 158-177 (2015).

5. Cavallo, E., Ferrari, E., Bollani, L., and Coccia, M. "Strategic management implications for the adoption of technological innovations in agricultural tractor: The role of scale factors and environmental attitude", Technology Analysis and Strategic Management, 26(7), pp. 765-779 (2014).

6. Meng, Q., Qiu, R., He, J., Zhang, M., Ma, X., and Liu, G. "Development of agricultural implement system based on machine vision and fuzzy control", Computers and Electronics in Agriculture, 112, pp. 128-138 (2015). 
7. Nicolae, M., Popescu, D., Merezeanu, D., and Ichim, L. "Large scale wireless sensor networks based on fixed nodes and mobile robots in precision agriculture", Mechanisms and Machine Science, 67, pp. 236-244 (2019).

8. Budaev, D., Lada, A., Simonova, E., Skobelev, P., Travin, V., Yalovenko, O., Voshchuk, G., and Zhilyaev, A. "Conceptual design of smart farming solution for precise agriculture", International Journal of Design and Nature and Ecodynamics, 13(3), pp. 307-314 (2018).

9. Zubko, V., Roubík, H., Zamora, O., and Khvorost, T. "Analysis and forecast of performance characteristics of combine harvesters", Agronomy Research, 16(5), pp. 2282-2302 (2018).

10. Izmailov, A.Y. "Intelligent technologies and robotic means in agricultural production", Herald of the Russian Academy of Sciences, 89(2), pp. 209-210 (2019).

11. Petrovna, D.-V., Alekseyevna, P.-S., Konstantinovna, O.-M., Valerievna, S.-A., and Antonovich, S.-Y. "Resource-saving technology for manufacturing of environmentally-friendly organic fertilizers", Dyna (Spain), 93(4), pp. 398-403 (2018).

12. Apazhev, A., Smelik, V., Shekikhachev, Y., and Hazhmetov, L. "Combined unit for preparation of soil for sowing grain crops", Engineering for Rural Development, 18, pp. 192-198 (2019).

13. Sietkaziev, A.S., Kulkaeva, L.A., and Shinysherova, G.B. "Rationale for water soil washing technologies by growth regulation", Periodico Tche Quimica, 15(30), pp. 578-588 (2018).

14. Xie, B., Wu, Z., and Mao, E. "Development and prospect of key technologies on agricultural tractor", Nongye Jixie Xuebao/Transactions of the Chinese Society for Agricultural Machinery, 49(8), pp. 1-17 (2018).

15. Bulinski, J. and Niemczyk, H. "Effect of moisture content in soil on its compaction caused by multipie running of agricultural vehicles", In Annals of Warsaw University of Life Sciences, pp. 3-8, Warsaw (2007).

16. Ratté-Fortin, C., Rousseau, A.N., Thériault, G., and van Bochove, É. "Evaluating the effects of BMPs on agricultural contaminants using a novel method accounting for uncertainty in water flow and contaminant loads", Canadian Water Resources Journal, 44(3), pp. 263-279 (2019).

17. Ageyev, L.Ye, Basics of Calculating the Optimal and Allowable Modes of Operation of Machine-Tractor Units, Leningrad: Kolos (1978).

\section{Biographies}

Edward 1. Lipkovich graduated in Machine Building from the Rostov Institute of Agriculture in 1958 and received his $\mathrm{PhD}$ in 1979. He attained the position of professorship in 1984, and became an academician of the Russian Academy of Agricultural Sciences in 1997 and an academician of RAS in 2013. Dr. Lipkovich is a prominent scientist in the field of mechanization, automation, and production of agricultural machinery. He worked as an engineer-constructor of the Rostselmash plant during 1958-1962 and engineer-designer of the State Special Design Bureau for a complex of grain harvesters, Rostov-on-Don, during 1962-1963. Also, he was the chief engineer of the harvesting laboratory during 1966-19674, senior research fellow during 19671969, head of the harvesting technology sector of the mechanization of harvesting department during 19691974, head of the department of technologies and means of harvesting mechanization during 1974-1989, deputy director for scientific work during 1989-1991, and director during 1991-2006 in the All-Russian NI and the design and technological institute of mechanization and electrification of agriculture. Since 2006, he has been the chief researcher of FGBOU HPE, AzovBlack Sea State Agroengineering Academy. He was the Laureate of the State Prize of the USSR in 1978, the Order of the Badge of Honor in 1976, the Veteran of Labor medal in 1985, and the winner of 3 VVC medals. Dr. Lipkovich has published about 300 scientific works, including 100 books and brochures and has over 40 copyright certificates and patents for inventions.

Andrey Y. Nesmiyan is Professor of Technical Sciences. In 1998, he graduated with honors from the FGOU VPO ACHAA (Zernograd, Rostov region, Russia), majoring in Mechanization of Agriculture. In 2002, he started working in the Department of Agricultural Machines and in 2007, he was assigned the chair of Mechanization of Plant Growing. In 2003, he was awarded the scientific degree of candidate of technical sciences and in 2007, the academic title of Associate Professor. From 2011 to 2016, Dr. Nesmiyan was the Head of the Department of Mechanization of Plant Production and since 2016, he has been Associate Professor in the Department of Technologies and Means of Mechanization of the Agro-Industrial Complex of the Azov-Chernomorsky Engineering Institute at FGBOU VO Donskoy State University (Zernograd, Rostov Region, Russia). In 2017, he became Professor in the same department. He is the author/co-author of more than 180 scientific works, including two monographs, and 30 articles published in the editions of the VAK list, and has 77 patents for inventions and utility models.

Sergey L. Nikitchenko is Associate Professor of Technical Sciences and the Head of the Department of Technical Service in the agro-industrial complex of the Azov-Chernomorsky Engineering Institute at FGBOU V Donskoy GAU in Zernograd. In 1996, he graduated from FGOU VPO ACHAA (Zernograd, Rostov region, Russia), majoring in Mechanization 
of Agriculture. From 1999 to 2005, he was Assistant and Associate Professor in the Department of Theoretical Mechanics at ACHAA and taught the disciplines of hydraulics, theoretical mechanics, the theory of mechanisms, and machines. In 2001, he defended his dissertation on "Improving the Efficiency of Using Energy-Saturated Tractors with a Reduced Technical Resource." During 2005-2006, he worked as a logistics operator in the field of trucking and goods circulation in the YUGTEHKOMPLEKT group of companies (Rostov-on-Don). Since 2007, he has been the senior lecturer in the Department of Mechanization of Plant Production and since 2012, the Head of the Department of Technical Service in the Agroindustrial Complex. He is the author of two monographs, 67 scientific articles including 19 in the list of VAK, and 12 educational and methodical publications. Dr. Nikitchenko has 8 certificates on state registration of software and 1 patent for utility model of the Russian Federation.

Vladimir V. Shchirov graduated in Mechanization of Agriculture from the FGOU VPO ACHAA (Zernograd, Rostov region, Russia) in 1999 in Since 2002, he has been the engineer-designer of the Institute of Agroengineering Problems (FGOU VPO ACHAA). Moreover, since 2012, he has been the Chief Designer of the IAP and since 2016, the head of the scientific and technical project of the Engineering and Transfer Center of the Azov-Black Sea Engineering Institute of the FGBOU VO Donskoy GAU (Zernograd, Rostov Region, Russia). Dr. Shchirov is the co-author of 5 articles at different levels and has 12 patents for inventions and utility models.

Yuriy G. Kormiltsev graduated in Electroacoustics and Ultrasonic Sound Equipment with honors from the Taganrog Radio Engineering Institute, V.D. Kalmykova (Taganrog, Rostov Region, Russia) in 1991. Then, he began working as the Chief Designer of the Priboy Plant in Taganrog. In 1994, he graduated from the special faculty for retraining the staff of the Taganrog State Radio Engineering University with specialty in Organization of Entrepreneurial Activities as manager-economist. In 1995, he organized and headed the enterprise for the production of spare parts of agricultural machinery in which the design department for the improvement of individual parts and units of agricultural machinery as well as the development of $\mathrm{CD}$ for new complete equipment was founded. Since 2001, Dr. Kormiltsev has been the General Director of Research and Production Tensor-T Research and Development LLC. He has 10 patents for inventions and utility models. 